\title{
Tuvan Traditional Culture as a Socio-Historical Phenomenon
}

\author{
A.K. Kuzhuget \\ Tuvan Institute of Humanitarian and Applied Socio-Economic Research \\ 4, Kochetova str., Kyzyl, 667000, Tuva Republic, Russian Federation
}

The nineties of the XX century are considered to be the starting point of crisis of traditional values in Russia, including moral, family, spiritual values. family, and spiritual values. The crisis was also marked in Tuva by the rise of unemployment, especially among Tuvan youth, and as a consequence, the search for new means of livelihood, with mass collection of cannabis, the growth of smuggling, cattle-stealing, poaching. All these social problems have one root of evil. It was during these years that the problem of the loss of intergenerational communication - which supported moral and ethical standards for many centuries - has been most clearly manifested. One of the reasons for this phenomenon is the mass construction of the boarding schools by Soviets in which the children of the shepherds lived and studied. Learning to read and write, they later refused to engage in traditional activities of the Tuvans - cattle breeding, and more importantly, they were deprived of spiritual education, ethical standards developed by their nation over the centuries. They have become carriers of a new feature - dependency. At that time, the first signs of social degradation have been shown, namely: anger, envy, mass alcoholism, the destruction of the institution of the family. However, this process has, admittedly, began as early as in 30-40s, when folk culture was actually banned, and a religion, rituals, holidays were not confessed. During the Soviet period, the country was dominated by the ideology of the Communist party, which was known to have both its negative and positive sides. Then the problem of interaction between nations was reduced to the influence of Russian culture, as an exemplary one; the cultures of other nations were considered as less developed and backward ones.

At present, the traditional culture of Tuvans, unfortunately, is permanently and inevitably experiencing the extinction of some types of artistic activities (in particular, the manufacture of saddles, bridles, utensils, traditional clothing and shoes, as well as folklore genres, traditions of etiquette) due to the modernization of society and changing lifestyle. The things that have been closely related to everyday life, go away first. Even more important is whether people's spiritual values leave or change. Since traditional culture is a historically developed system, which for many centuries has been developing and selecting spiritual values, behavioral norms, traditions, it is itself a means of nationbuilding. It is this fact that is not taken into account by modern political and administrative moderators. Admittedly, the Tuvan society has lost many of its value orientations for just 70 years of Soviet regimen, since 1944 - a year of accession of People's Tuvan Republic 
to the USSR. Children and old people were the most loved and honored in the traditional Tuvan society, but today there are dozens of orphanages and nursing homes in the Republic of Tuva. High mountains, rapid rivers, mineral springs, salt lakes are no longer the objects of careful use and worship for modern Tuvans, as it was before. The very concept of LABOR of nomad - shepherd and cattleman - has now lost its ancient value as the meaning and way of life, being replaced by the other concepts - ocalism, forwardness to use any means to receive various benefits and stealing of cattle.

That is why the research of the spiritual culture of traditional society, the study of its components, its potentials related to the view of life, the attitude to nature and people are of increasing importance nowadays. It is necessary to turn back the harmonious vector of development of age-old culture, because nowadays the tradition becomes a formality of fulfillment of a certain set of certain actions, without understanding their sacred significance.

The durability of spiritual culture is explained by its self-containment and synergy. The spiritual culture of traditional society teaches the ability to achieve psychological comfort in life, to enjoy simple human feelings - love for a woman and a child, friendship, living in step with nature and with yourself.

The recent decades in Tuva have shown that blindly following the experience of developed (Western) civilizations is not always acceptable. It is well known that in the field of economy and production the influence of Western technologies has accelerated the development of Eastern societies. But in the spiritual field the problems of the modern crisis have only deepened, have become a real humanitarian disaster.

No culture can (and could not previously) develop on its own. The process of interaction with other cultures has been ongoing throughout the existence of any culture since its inception. Since the 20 s of the XX century the process of time-honoured communication and cultural interaction of Tuva with Mongolia, China and indirectly through them with other Asian countries, as previously with the neighboring Turkic nations of Siberia, was interrupted. Meanwhile, the relations between the Tuvans and their Eastern neighbors were extremely strong and long. Tuvan art critics and culturologists note that their influence was reflected in all kinds of folk art of Tuvans: in music, oral folk arts, decorativeapplied arts, sculpture and, as a whole, in the perspective of the Tuvan people's mentality.

In Soviet times, in order to achieve the highest goal - the alignment of Russian culture from Moscow to the outskirts, through sharp changes in the political and socio-economic development of Tuvan society, the measured and quiet rhythm of life of Tuvans in harmony with their neighboring nations was replaced with a sense of psychological discomfort.

A vast range of issues of Tuva culture modernization is definitely associated with its Eastern-to-Western transformation. There is a concept of naturalization, in particular, the elements of another culture, and there is copying. The naturalization should be meaningful, it is necessary to look for points of contact in own culture: the naturalized elements should be clear and acceptable for people; only this way will be rational.

There was a lot of things in the Soviet Union that were incomprehensible and even unacceptable to the Eastern people's mentality. The rigidity of the Communist cultural policy eliminated only external problems, leaving the root of problems deep inside the Tuvan people's subconsciousness. The most dismal result of the Soviet modernization 
of the Tuvan society and culture was the development of complex of national inferiority, admission of the idea of the backwardness of the Tuvan culture and its incompatibility with the new culture, and hence - a complete rejection of it by the nation itself, at least officially. All ill-considered policy led to the conflicts of the 1990s in Tuva.

More and more scientists and writers mention that history is the most important area of knowledge for society. However, politicians in Russia reject these simple truths with surprising persistence. In Soviet Russia, the scope of scientific research was exclusively aimed at the influence of Russian Soviet culture on Tuvan, however, in this area the approach was quite formal, declarative and politically charged. How much has the modern Tuvan culture changed? What positive and negative processes are taking place in it? These questions remain practically unexplored. In-depth study of these questions, both on philosophical and cultural basis, is of high demand by society, but is not welcomed by the authorities, as the shortcomings of socio-cultural policy will become evident. Currently, the authorities have new levers of control over the development of humanitarian science: projects supported by the Ministry of education and the state task of the government.

After the collapse of the Soviet Union, the social and cultural life of its nations, especially of the "titular Nations", has started the process of turning to its past, to the origins and roots. However, it was not always meaningful, often it was a setback, almost a transition to feudal relationship, to the archaic behaviour patterns.

Under the guise of "the revival of culture" in the national republics where feudal relations have not been outgrown, in fact, the reconstruction of the clan system has begun. Unfortunately, government officials and authority representatives ignore the appeals of cultural scientists, philosophers, literary critics and art critics not only in Tuva. This potential of the Republic is practically undeveloped. The cultural policy is created quite formally by cultural officials, without expert advise of the scientists. Concerts and diplomas for various festivals are, according to officials, the most important indicator of the culture development of the Republic.

National culture cannot be isolated, but its basic values must be maintained. One of them is religion as an essential part of any culture. The institution of the traditional Tuvan family is being destroyed, the role of the father as a head of family is decreasing. Rules of national etiquette in particular, the treatment of the elderly and children are being forgotten or preserved formally, without comprehension; traditions of education are forgotten. The rituals including wedding, funeral are being distorted, without taking into account national ethical standards.

Culture is not only songs, dances, and not only ancient throat singing, but in the first - the spiritual ethnic values. The attempts to maintain the traditions in their old form are vain: the world is changing, and modern people can not perceive it as their ancestors a hundred years ago. But both are the representatives of one nation. And first of all, they should be United by spiritual values. Otherwise, the culture becomes a genetically modified product, a mutant. Very soon this process can become irreversible, it can lead to splitting the society into marginal groups, disintegration and xenophobia. Social scientists constantly state that Russian culture in general is in danger; the culture of the national republics is in danger in particular. The main problems of these days are inter-ethnic relations and crisis of identity. The identity is usually regarded as affiliation 
of the individual to the culture, tradition, system of values and norms of a particular society. Identity is a way of self-understanding and the most important form of human self-assertion.

National identity, therefore, implies the adoption by the person the national image of the world, history and spiritual values. It is known that a person fostered from early childhood according to the norms and rules enshrined in traditional etiquette, knowing his culture, language, history, is much better adapted to the socio-cultural space, even when it is completely new to him. In the world of globalization the person perceives himself/herself holistically, without experiencing such a discomfort as a person who has lost his national or regional identity.

The fundamental discrepancy of modern times and the main challenge to humanity in the XXI century is the confrontation of universal civilization standards, on the one hand, and the values of national cultural and religious identity, on the other hand.

In the Russian National Security strategy until 2020 it is written:

" 84 . The addressing a problem of ensuring national security in the sphere of culture in mid-term and long-term perspective is achieved by recognizing the primary role of culture for the revival and preservation of cultural and moral values, strengthening the spiritual unity of the multinational people of the Russian Federation and the international image of Russia as a country with the richest traditional and dynamically developing modern culture, creating a system of spiritual and Patriotic education of Russian citizens, developing a common humanitarian and information and telecommunication environment across the member States of the Commonwealth of Independent States and in bordering regions".

The solving of purely economic problems is impossible without addressing the issues of spiritual development of modern Tuvan society. In the East, it was understood as early as in the XIX century (for example, in Japan they have been teaching moral lessons in schools for more than a hundred years); in the West, it is now only about talking, discussing, while it is time to act advisedly. It is necessary to create in the Republic of Tuva effective and really working cultural programs that take into account features of mentality and national character. Admittedly, the ministries that act independently when adopting development strategies until 2030, should act in a coordinated manner in terms of education; this applies primarily to the field of education and culture. An example of such fruitful cooperation is the agreement on partnership of the Ministry of education with the Tuvan State puppet theatre on staging the works of world classics included in the school curriculum. The Tuvan national orchestra created several programs that introduce young people to the masterpieces of folk music and tell the story of the instruments. It's unfortunate that not so many urban children of different nationalities visit their concerts as we would like. A good administrative approach would address this issue.

In our opinion, the opportunities of the Philharmonic Symphony orchestra, which could organize subscription concerts on the works of world classics for youth, are not used to the full extent.

It is necessary to expand the duration of humanitarian cycle subjects in schools, colleges and universities where the culture of Tuva - of Tuvan and Russian people, first of all - 
is studied deeply, as well as the worldview attitudes of a citizen of modern Russia. For example not all schoolchildren know the essence of both Russian Orthodox holidays and state Tuvan holidays.

Tolerance should be the basic concept in cross-cultural interaction. But in practice, the modern society is destined for a civil position developed more on the horizontal than on the vertical level, which means the interaction of public organizations, educational and cultural institutions.

It is necessary to look for new forms and technologies of tolerance education. As we know from the experience of the countries of South-East Asia, a careful distinction between national and cultural basic values and innovations allows not to lose the identity and to be extremely interesting for other nations and, most importantly, to exclude internal social and moral conflicts of the community. The most important feature of our society should be the mutual respect.

Thus, it is necessary to accept the fundamental truth that new generations will be developed in a diversity environment; for this, the cultural and educational system should teach people respect for the heritage of the nations of our country. It is necessary to return, not only in words, the traditional forms of behavior regulation, which were forced out and forgotten by modern society, with a detailed explanation and discussion of the basic concepts in the adolescent and youthful environment. The loss of family traditions, the status of the family as the key factor in the education of the child, the loss of behavioral stereotypes of parents, have led to the destabilization of Tuvan society. Currently, fatherhood needs to be updated, not mechanistically, but in accordance with traditional rules. There should be a historical continuity. Without it, as clearly seen now, the society becomes spiritually wild.

The culture of making dialogue is necessary for building social harmony and peace. In this regard, the study of languages is of special importance. It would be good to adopt, for example, the practice of Kazakhstan, where all students must have proficiency at least in three languages: Kazakh, Russian and English.

The innovations took place in any culture in the past - without it the development of the mankind is impossible; but we need thoughtful and critical inclusion of globalization process in our culture.

In connection with these tasks, the humanitarian sciences play the increasingly important role: the society needs analytical centers, public organizations supported by charitable foundations, which will work out political decisions in the field of cultural and ethno-confessional security, will determine the ways of social development, which will cover monitoring for the implementation of government policy, to predict and produce options for updating the socio-cultural environment.

(C) Kuzhuget A.K., 2018

\section{Article history:}

Received: 17.06 .2018

Accepted: 26.09.2018

Moderator: U.M. Bakhtikireeva

Conflict of interests: none 
For citation:

Kuzhuget, A.K. 2018. "Tuvan Traditional Culture as a Socio-Historical Phenomenon". Polylinguality and Transcultural Practices, 15 (4), 632-637. DOI 10.22363/2618-897X-2018-154-632-637

\title{
Bio Note:
}

Aylana K. Kuzhuget is a Doctor of Culturology, Candidate of Art History, Chief Researcher of Tuvan Institute of Humanitarian and Applied Socio-Economic Research, Honored Worker of Education of the Republic of Tuva. E-mail: akumin@mail.ru

\section{Тувинская традиционная культура как социально-исторический феномен}

\author{
А.К. Кужугет \\ Тувинский институт гуманитарных и прикладных социально-экономических исследований \\ Республика Тыва, 667000, Кызыл, ул. Кочетова, д. 4 \\ История статьи: \\ Поступила в редакцию: 17.08.2018 \\ Принята к публикации: 26.09.2018 \\ Модератор: У.М. Бахтикиреева \\ Конфликт интересов: отсутствует

\section{Для цитирования:} \\ Kужугет A.K. Тувинская традиционная культура как социально-исторический феномен // \\ Полилингвиальность и транскультурные практики. 2018. Т. 15. № 4. С. 632-637. DOI \\ 10.22363/2618-897X-2018-15-4-632-637 \\ Сведения об авторе: \\ Кужугет Айлана Калиновна - доктор культурологии, кандидат искусствоведения, главный \\ научный сотрудник Тувинского института гуманитарных и прикладных социально-эко- \\ номических исследований, заслуженный работник образования Республики Тува. E-mail: \\ akumin@mail.ru
}

